\title{
Cleaner fish Labroides dimidiatus reduce 'temporary' parasitic corallanid isopods on the coral reef fish Hemigymnus melapterus
}

\author{
A. S. Grutter ${ }^{1, *}$, R. J. G. Lester ${ }^{2}$ \\ ${ }^{1}$ Department of Zoology and Entomology and ${ }^{2}$ Department of Microbiology and Parasitology, The University of Queensland, \\ Brisbane, Queensland 4072, Australia
}

\begin{abstract}
To determine if cleaners affect 'temporary' parasitic corallanid isopods (Argathona macronema) on fish, we used caged fish Hemigymnus melapterus (Labridae) on 5 patch reefs on Lizard Island, Great Barrier Reef, and removed all cleaner fish Labroides dimidiatus (Labridae) from 3 of the reefs. In a short-term experiment, fish were sampled after 12 or $24 \mathrm{~h}$, at dawn and sunset respectively, and in a long-term experiment they were sampled after $12 \mathrm{~d}$ at sunset. Isopod prevalence, abundance and size were measured. In the short-term experiment, on reefs without cleaners the prevalence of A. macronema was higher after $24 \mathrm{~h}$ than after $12 \mathrm{~h}$ while on reefs with cleaners, prevalence was low at all times. Although the abundance of $A$. macronema did not vary after 12 and $24 \mathrm{~h}$, when combined over the $24 \mathrm{~h}$, the effect of cleaners was significant with only $2 \%$ of all the A. macronema found on reefs with cleaners. Cleaners had no effect on the size frequency distribution of A. macronema in the short-term experiment, most likely because fish had so few isopods on reef with cleaners. In the longer-term experiment, the effects of cleaners on isopod prevalence and abundance were less clear. Their effect on isopod size was, however, significant with smaller parasites on reefs without cleaners. The reduction of isopod prevalence and abundance by cleaner fish over a period of hours may explain why these A. macronema are rare on wild fish. Our findings support the idea that cleaning is beneficial to clients and has important implications for the control of parasites of fish farmed in cages.
\end{abstract}

KEY WORDS: Cleaning behaviour $\cdot$ Labroides dimidiatus $\cdot$ Corallanidae $\cdot$ Isopoda $\cdot$ Cleaner fish Resale or republication not permitted without written consent of the publisher

\section{INTRODUCTION}

Cleaning is one of the most common behaviours of coral reef fish with many species using the services of cleaners (Kuwamura 1976, Grutter \& Poulin 1998, Wicksten 1998). It has generally been assumed that cleaning is mutualistic with cleaners obtaining food from cleaning (Randall 1958, Youngbluth 1968, Grutter 1997) and clients benefiting from a reduction in parasites (Limbaugh 1969). The effect of cleaners on parasites, however, is controversial and has been questioned several times (Losey 1972, 1979, 1987, Weeks

*E-mail: a.grutter@mailbox.uq.edu.au
2000). Recently, however, it has been shown that cleaners affect the size of parasitic copepods (Gorlick et al. 1987) and abundance of parasitic gnathiid isopods on client fish (Grutter 1999a).

Reef fish, however, are also infected by parasites other than copepods and gnathiids (Burreson \& Dybdahl 1989, Lester \& Sewell 1989, Grutter 1994, Rohde et al. 1994, Chisholm \& Whittington 1996, Diggles \& Lester 1996, Whittington 1998). Hosts would therefore also likely benefit from the removal of these parasites by cleaners, particularly if they are harmful. Although little is known of the effects of most tropical parasites on fish condition (Adlard \& Lester 1994, Williams \& Bunkley-Williams 1996), it is likely that isopods in the suborder Flabellifera, in addition to Gnathiidea, may 
be some of the more harmful parasites of reef fish (Adlard \& Lester 1994, Lester \& Roubal 1995).

There is some evidence that fish in the Caribbean may use cleaner shrimp to remove isopods. In a laboratory experiment examining the effects of 4 species of cleaner fishes (Bodianus rufus, Gobiosoma evelynae, Pomacanthus arcuatus and Thalassoma bifasciatum) and 4 species of cleaner shrimp (Stenopus hispidus, $S$. scutellus, Lysmata grabhami and Periclimenes pedersoni), the latter were observed to remove all newly settled juvenile Anilocra haemuli (Cymothoidae) isopods from the French grunt Haemulon flavolineatum and eat all of them (Bunkley-Williams \& Williams 1998a). It is possible that cleaner fish remove isopods, other than gnathiids, from fish in the wild as a small number of cymothoid isopods have been found in the diet of the cleaner fish Labroides dimidiatus (Choat 1969).

New problems related to infections have arisen with the increased aquaculture of tropical fish species (Roubal 1995, Chi et al. 1997, Koesharyani et al. 1999, Zafran et al. 2000). Thus, there is a need for information on the control of parasites on farmed fish. Cleaner fish have been used to control parasites, mainly caligid copepods, of salmon in temperate fish farms (Costello 1995) and for controlling monogeneans on farmed tilapia (Cowell et al. 1993). To date, no studies have been made on the use of tropical cleaner fish for controlling isopods, other than gnathiids (Grutter 1999a), on confined fish.

Although most are free-living, corallanid isopods can also be temporary associates; on fishes they are either commensal or parasitic (Bowman 1977, Bruce 1982, Delaney 1989, Ho \& Tonguthai 1992, Williams \& Bunkley-Williams 1994b, Bunkley-Williams \& Williams 1998b). In a study examining the effects of the cleaner fish Labroides dimidiatus on gnathiid isopods on caged wrasse Hemigymnus melapterus on reefs with and without cleaner fish (Grutter 1999a), Argathona macronema corallanid isopods were also found but not discussed. In the present study, we examined the effect of cleaners on prevalence, size and abundance of $A$. macronema on the same caged fish as in the study by Grutter (1999a), where only gnathiids were considered. Because cleaner fish are only active during the day (Grutter 1996a), the experiment also tested whether the effect of cleaners varied between day and night.

\section{MATERIALS AND METHODS}

Removal of cleaner fish. To determine if cleaners affect Argathona macronema, we caged Hemigymnus melapterus on 5 coral reefs on Lizard Island, Great Barrier Reef. All Labroides dimidiatus were removed from 3 reefs on December 27 and 29, 1997, and released on other reefs. Adult cleaner fish were captured with a $1.5 \times 1 \mathrm{~m}$ barrier net and hand net (both $10 \mathrm{~mm}$ mesh); juveniles, identified by their distinct color pattern (Potts 1973), were captured with a $2 \times 2 \mathrm{~m}$ barrier net and handnet (both $2 \mathrm{~mm}$ mesh). The standard length of adults (juveniles) removed from reefs was: Reef 14: 53, 58, 65, 68 (36) mm; Reef 15: 49, 54, 55, 68, $71(11,48) \mathrm{mm}$; Reef 16: 47, 53, 57, $58(18,35)$ (see Grutter 1996b for map of reefs). These reefs remained free of $L$. dimidiatus for the duration of the study. The number of adult (juvenile) cleaner fish on control Reefs 7 and 8 was 2 (2) and 4 (1), respectively; the standard length range of adults and juveniles was estimated visually as 50 to $70 \mathrm{~mm}$ and 25 to $30 \mathrm{~mm}$, respectively.

Sampling of parasites. We compared the number of Argathona macronema on caged (for cage dimensions see Grutter 1999b) fish on reefs with and without cleaner fish at sunset after $12 \mathrm{~d}$. To determine whether differences in isopod abundance between treatments differed between dawn and sunset, fish were again placed on the same reefs the following sunset and half of the cages recovered the next dawn and the other half the next sunset. Six cages, each holding 3 fish, were placed on each of the reefs (initial total number of fish $=$ 90, see Table 1 for final sample sizes of fish). The present study was done $4 \mathrm{~d}$ after Grutter (1999b) and used those same fish and handling and transport procedures. Cages were placed on reefs at dawn (06:00 h) on a different reef that was randomly selected each successive day. Sampling began on January 12, 1998 (no cages were put out on January 13, 1998, due to weather constraints). Fish were fed daily on prawn pieces, skewered on a wire and attached to the center of cage.

After $12 \mathrm{~d}$, fish were recovered at 18:00 h. Argathona macronema, found on the body and in the water they were transported in, were removed, fixed and counted and their length (excluding uropods) measured (Grutter 1999b). All isopods that were not gnathiids were identified as A. macronema (Bruce 1982). These were mostly juveniles and a few adults (N. Bruce pers. comm.) and were found in the gills and mouth of Hemigymnus melapterus. The width (gut) of A. macronema for a given length (Grutter 2000) was determined from a subsample $(n=97)$ collected in the $24 \mathrm{~h}$ experiment. A subsample was used due to the large amount of time required to measure the width of each individual. Fish were held in cages in $3 \mathrm{~m}$ diameter holding tanks until the following sunset. The next day, we placed the same caged fish on the same reef at sunset $(18: 00 \mathrm{~h})$; fish which were missing due to deaths or losses (escapes and attacks on 2 cages) in the $12 \mathrm{~d}$ experiment were substituted with other fish which had been held in cages in the laboratory. On each reef, 3 randomly chosen cages were collected the following dawn $(12 \mathrm{~h}$ later), and the 3 remaining cages collected the next 
Table 1. Summary of several variables measured in the $12 \mathrm{~d}$ and $24 \mathrm{~h}$ experiment on reefs with and without cleaner fish Labroides dimidiatus. Variables are: (1) abundance of Argathona macronema isopods on caged Hemigymnus melapterus; (2) the prevalence of these isopods on $H$. melapterus; and (3) the final number of caged $H$. melapterus per reef

\begin{tabular}{|c|c|c|c|c|c|c|}
\hline Variable & $\begin{array}{l}\text { Sampling } \\
\text { time }\end{array}$ & $\begin{array}{c}\text { Reef } 7 \\
\text { With } \\
\text { cleaners }\end{array}$ & $\begin{array}{c}\text { Reef } 8 \\
\text { With } \\
\text { cleaners }\end{array}$ & $\begin{array}{c}\text { Reef } 14 \\
\text { Without } \\
\text { cleaners }\end{array}$ & $\begin{array}{c}\text { Reef } 15 \\
\text { Without } \\
\text { cleaners }\end{array}$ & $\begin{array}{c}\text { Reef } 16 \\
\text { Without } \\
\text { cleaners }\end{array}$ \\
\hline Isopod abundance & $12 \mathrm{~d}$ & 1 & 21 & 45 & 52 & 10 \\
\hline Isopod prevalence & $12 \mathrm{~d}$ & 1 & 8 & 6 & 12 & 5 \\
\hline Final total fish & $12 \mathrm{~d}$ & 13 & 11 & 13 & 14 & 7 \\
\hline Isopod abundance & $24 \mathrm{~h}$ (12 h night only) & 2 & 1 & 1 & 0 & 32 \\
\hline Isopod abundance & 24 h (night and day) & 1 & 0 & 12 & 6 & 55 \\
\hline Isopod infected fish & $24 \mathrm{~h}$ (12 h night only) & 1 & 1 & 1 & 0 & 4 \\
\hline Isopod infected fish & 24 h (night and day) & 1 & 0 & 5 & 3 & 5 \\
\hline Final total fish & $24 \mathrm{~h}$ (12 h night only) & 9 & 9 & 9 & 9 & 9 \\
\hline Final total fish & 24 h (night and day) & 9 & 9 & 6 & 9 & 6 \\
\hline
\end{tabular}

sunset (24 h later). A. macronema were quantified as above ( 2 isopods could not be measured as part of their body was missing). We tested for the effects of replacing fish, sampling time and presence of cleaner fish.

The cleaning behaviour of Labroides dimidiatus. The occurrence of cleaning in cages was noted daily by a SCUBA diver. Once cleaning was observed consistently by a diver, the rate at which fish in cages were cleaned per 30 min was recorded following Grutter (1995). The number of fish (number of observations per reef) in cages on Reefs 7 and 8 was 11 (4) and 13 (3), respectively. The overall mean duration of cleaning inspection and standard error (SE) were calculated using a weighted average and pooled variance (Zar 1999). The total duration of inspection of each individual caged fish received between dawn and sunset in the $24 \mathrm{~h}$ experiment was calculated assuming a $12 \mathrm{~h}$ day (following Grutter 1996a), which was divided by the number of fish per reef $(n=9)$. We assumed that the total amount of time over $1 \mathrm{~d}$ that cleaners spent inspecting caged fish was independent of the number of fish in cages. This is a reasonable assumption as the number of fish in cages was only a small proportion of the several 100s of fish on reefs (A. Grutter pers. obs.). For comparison with caged fish the cleaning rates of wild Hemigymnus melapterus from Grutter et al. (2002, in this issue) were used and a mean rate per day calculated as above.

Statistics. Analysis of variance was not used to test for an effect of cleaners as zeros were linked to one of the treatments; thus, violating the assumption of independence of the analysis. Goodness of fit $\chi^{2}$ analyses were therefore used to compare the observed abundances of Argathona macronema per treatment to expected values. Expected values for a treatment were obtained by multiplying the relative infection rate (RIR) for that treatment by the sum of all abundances. The RIR was obtained by dividing the prevalence for a treatment (number of infected fish per treatment divided by total number of fish per reef) by the sum of the prevalences for all treatments. The RIR was used because it accounted for the number of fish per reef. Fisher's exact tests were done using StatExact-3 version 3.0.2, Cytel Software Corporation. In the $24 \mathrm{~h}$ experiment, the prevalence and number of A. macronema per combination of reef, time of day and whether they had been replaced or not were too low to conduct separate analyses per reef. Therefore, they were summed across reefs within a treatment for the statistical analyses. The size classes of $A$. macronema were chosen to maximize sample sizes for statistical analyses.

\section{RESULTS}

\section{Cleaning behaviour of Labroides dimidiatus}

Repeated cleaning of caged fish was observed on Reefs 7 and 8 after cages had been on reefs for 9 and $8 \mathrm{~d}$, respectively. Most of the cleaning observed by divers was done by the smallest juvenile cleaner Labroides dimidiatus. Individual cleaners spent a mean (SE) 5.57 (0.82) min per $30 \mathrm{~min}$ or an estimated 133.7 (19.68) min $\mathrm{d}^{-1}$ inspecting Hemigymnus melapterus. Each individual fish exposed to Argathona macronema between dawn and sunset in the $24 \mathrm{~h}$ experiment was thus inspected by cleaners for an estimated 14.9 (2.18) min $\mathrm{d}^{-1}$. This rate is similar to that of wild $H$. melapterus which are inspected by cleaners an estimated 16.7 (1.2) $\operatorname{min~}^{-1}$ (Grutter et al. 2002).

\section{Size range of Argathona macronema}

The relationship between length and width of Argathona macronema was expressed as width $(\mathrm{mm})=$ $0.1102+0.3904$ (length in $\mathrm{mm}), \mathrm{r}^{2}=0.91, \mathrm{n}=97$. The 
size range of $A$. macronema across both experiments was 2.5 to $16.6 \mathrm{~mm}$. Thus, the estimated width of these was 1.09 and $6.59 \mathrm{~mm}$, respectively.

\section{Argathona macronema in $12 \mathrm{~d}$ experiment}

The abundance of Argathona macronema on fish varied significantly among reefs, (Goodness of fit $\chi^{2}=$ 12.21, df $=3, \mathrm{p}=0.007$ ), with reefs with cleaners (Reefs 7 and 8) having fewer A. macronema than expected and with 2 out of 3 reefs without cleaners (Reefs 14
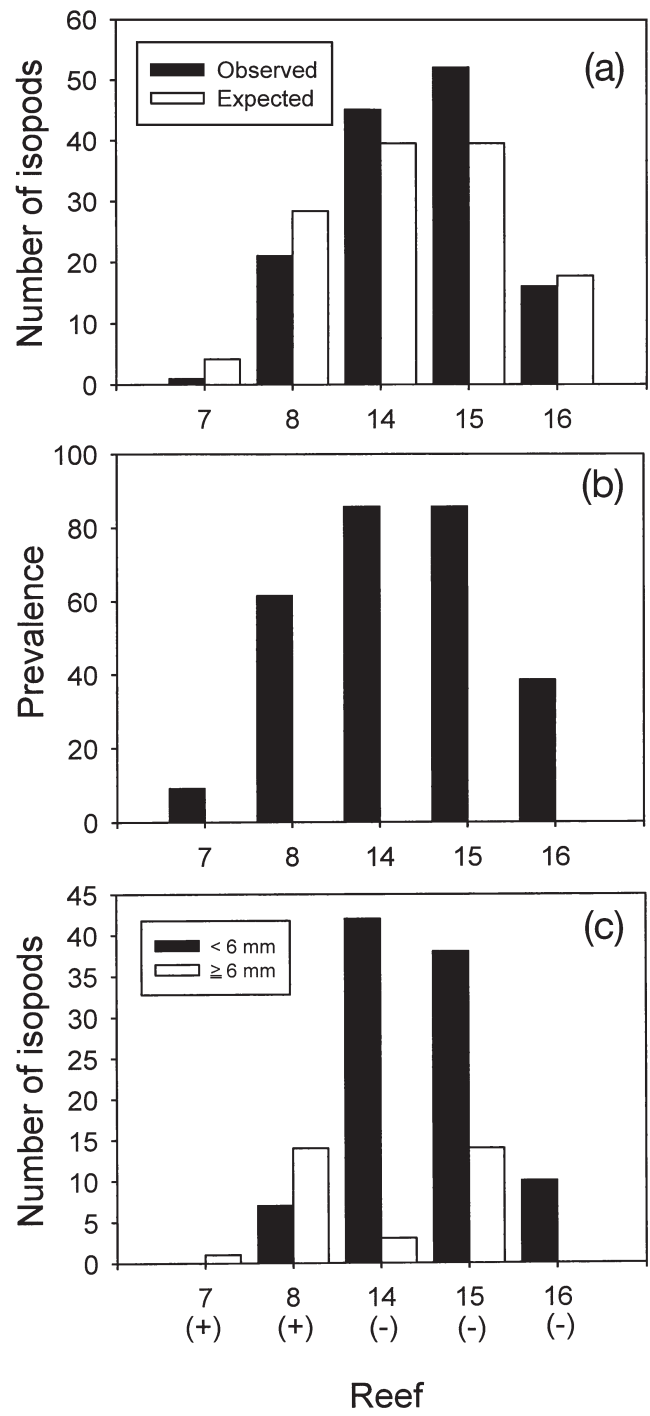

Fig. 1. Argathona macronema isopods on caged Hemigymnus melapterus after $12 \mathrm{~d}$ on reefs with $(+)$ and without (-) cleaner fish Labroides dimidiatus. (a) Number of isopods on fish per reef (observed) compared to expected values. (b) Prevalence (percent infected) of isopods on fish per reef. (c) Number of isopods per size class of isopods on fish per reef. See 'Materials and methods' for calculation of expected values and 15) having more A. macronema than expected (Fig. 1a). The prevalence (proportion of infected fish) of A. macronema also varied among reefs (Pearson's $\left.\chi^{2}=19.05, \mathrm{df}=4, \mathrm{p}<0.001\right)$, with the lowest prevalence found on one of the reefs with cleaners (Reef 7) and the highest found on 2 reefs without cleaners (Reefs 14 and 15) (Fig. 1b).

The size of Argathona macronema ranged from 3.5 to $15.0 \mathrm{~mm}$. Although Reef 16 had only small A. macronema, overall, the relative size frequency distributions of isopods per reef were similar within a treatment (Fig. 1c) and were therefore pooled across reefs. There were more small A. macronema (84\%) on fish from reefs without cleaner fish than on fish from reefs with cleaner fish (32\%) (Fisher's statistic $=23.17, \mathrm{p}<0.001)$.

\section{Argathona macronema in $24 \mathrm{~h}$ experiment}

\section{Prevalence of Argathona macronema}

The proportion of 'new' fish did not vary between cleaner fish treatments, with $35 \%$ of fish on reefs without cleaners replaced with 'new' fish and 36\% replaced on reefs with cleaner fish. On reefs without cleaners, there was no effect of replacing fish on the proportion of infected fish held $12 \mathrm{~h}$ overnight (Fisher's statistic $=0.409, \mathrm{p}=0.648$ ) (Fig. 2a); there was, however, a significant effect of replacing fish over the $24 \mathrm{~h}$ day (Fisher's statistic $=5.00, \mathrm{p}=0.042$ ), with 'old' fish (those not replaced) being more infected (72\%) compared to 'new' fish ( $0 \%$ ) (Fig. 2a). In contrast, on reefs with cleaners, this pattern did not differ between the $12 \mathrm{~h}$ night and $24 \mathrm{~h}$ day, with no effect of replacing fish on the proportion of infected fish both for fish held over the $12 \mathrm{~h}$ night (Fisher's statistic $=0.28, \mathrm{p}>0.999$ ) or over the $24 \mathrm{~h}$ day (Fisher's statistic $=2.38, \mathrm{p}=0.278$ ) (Fig. 2b).

As there was no effect of replacing fish on reefs with cleaners, the samples were pooled across this factor to examine the effect of time of day (12 h night or $24 \mathrm{~h}$ day) on the proportion of infected fish. There was no effect of time of day on the proportion of fish infected (Fisher's statistic $=0.44, \mathrm{p}>0.999$ ).

Because of the significant effect of replacing fish on fish sampled during the $24 \mathrm{~h}$ day only the 'old' fish were considered. On reefs without cleaners the proportion of 'old' fish that were infected was higher for fish held over the entire $24 \mathrm{~h}$ day $(72 \%)$ than over the $12 \mathrm{~h}$ night $(12 \mathrm{~h})(23 \%)$ (Fisher's statistic $=7.15, \mathrm{p}=$ 0.011). In contrast, on reefs with cleaner fish the proportion of 'old' fish that were infected did not differ between the $12 \mathrm{~h}$ night and $24 \mathrm{~h}$ day, with $10 \%$ and $0 \%$ prevalences, respectively (Fisher's statistic $=1.28$, $\mathrm{p}=0.435)$. 


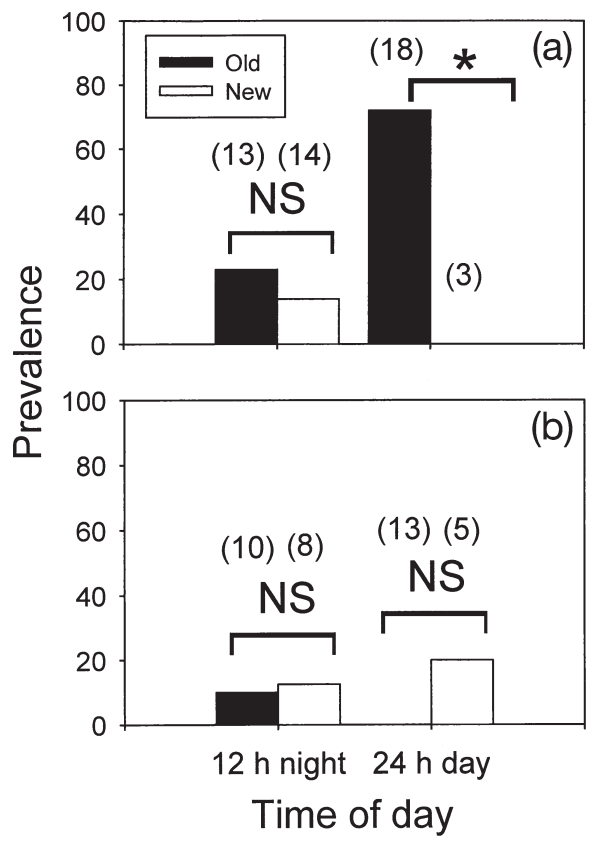

Fig. 2. Prevalence of Argathona macronema isopods on caged Hemigymnus melapterus in the $24 \mathrm{~h}$ experiment, after a $12 \mathrm{~h}$ night and after a $24 \mathrm{~h}$ day on (a) reefs without cleaner fish Labroides dimidiatus and (b) reefs with cleaner fish. Old $=$ fish used in the $12 \mathrm{~d}$ experiment; New = fish that were replaced with fish not used in the $12 \mathrm{~d}$ experiment. Horizontal bars indicate Fisher's exact tests; ns $=p>0.05 ; *<0.05$. Numbers in brackets indicate sample sizes of fish

\section{Abundance of Argathona macronema}

On fish held in cages over the $12 \mathrm{~h}$ night on reefs without cleaners, there were more Argathona macronema than expected on 'old' fish and less observed than expected on 'new' fish (goodness of fit $\chi^{2}=7.43$, $\mathrm{df}=1, \mathrm{p}=0.006$ ) (Fig. 3a). Similarly, for fish held over the $24 \mathrm{~h}$ day, only 'old' fish had A. macronema (Fig. $3 a)$. Because of the potential effect of replacing fish on reefs without cleaners these data were not pooled across this factor for further analyses. In contrast, on reefs with cleaners the numbers of $A$. macronema on caged fish were too low to test for an effect of replacing fish or time (12 h night or $24 \mathrm{~h}$ day) (Fig. 3b).

Because of the significant effect of replacing fish above, only 'old' fish were considered. For these, the effect of time on isopod abundance on reefs without cleaners was not significant (goodness of fit $\chi^{2}=0.58$, $\mathrm{df}=1, \mathrm{p}=0.446) ;$ on reefs with cleaners the observed and expected values of Argathona macronema were $\leq 2$ per time and so the effect of time could not be tested. As there was no evidence of an effect of time, samples were pooled across times and tested for the effect of cleaner presence; significantly more A. macro- nema (102 isopods) were found on 'old' fish from reefs without cleaners than on reefs with cleaners (2 isopods) (goodness of fit $\chi^{2}=4.96, \mathrm{df}=1, \mathrm{p}=0.026$ ).

\section{Size of Argathona macronema}

The size range of Argathona macronema was 2.5 to $16.6 \mathrm{~mm}$. The effect of replacing fish within a time of day and within a cleaner treatment was only examined for fish held over the $12 \mathrm{~h}$ night on reefs without cleaners, as all other combinations had zeros and/or small samples sizes per size class ( $\leq 2$ isopods); replacing fish had no effect on the size frequency of isopods (Fisher's statistic $=2.79, p=0.128$ ). As there was no evidence of an effect of replacing fish (see above), samples were pooled across this factor and tested for an effect of time of day. The effect of time was not significant both on reefs without cleaners (Fisher's statistic $=1.77, \mathrm{p}=$ 0.208 ) and on reefs with cleaners (Fisher's statistic $=$ $2.90, p=0.250$ ). As there was also no evidence of an effect of time of day on the size frequency distribution of A. macronema, samples were pooled across this factor and tested for an effect of cleaners. The size frequency distribution of $A$. macronema did not vary between reefs with and without cleaners (Fisher's sta-

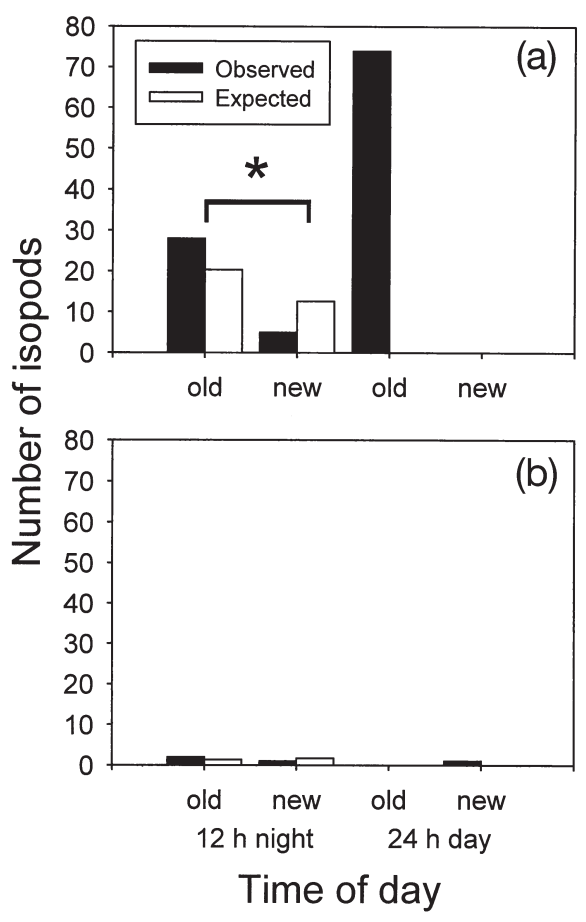

Fig. 3. Number of Argathona macronema isopods on caged Hemigymnus melapterus per treatment in the $24 \mathrm{~h}$ experiment, after a $12 \mathrm{~h}$ night and after $24 \mathrm{~h}$ day on (a) reefs without cleaner fish Labroides dimidiatus and (b) reefs with cleaner fish. Legends and axes as described in Figs. 1 \& 2 
tistic $=0.935, \mathrm{p}=0.618)$ with 3 small and 1 large isopod, and 52 small and 53 large A. macronema on reefs with and without cleaners, respectively.

\section{DISCUSSION}

\section{Isopod abundance and infection}

The cleaner fish Labroides dimidiatus affected the prevalence, abundance and size frequency distribution of Argathona macronema isopods on the caged fish Hemigymnus melapterus held on patch reefs at Lizard Island. Similarly, Grutter (1999a) found that cleaner fish affected the abundance of parasitic gnathiid isopods on these same caged $H$. melapterus. These 2 subsets of a larger study, in addition to Limbaugh's (1961) qualitative study, are the only studies to show that cleaner fish affect the abundance of parasites of fish. These studies and Gorlick et al.'s (1987) study, in addition to studies showing that parasite infection is a proximate cause of cleaning behaviour in clients (Grutter 2001), support the idea that cleaning behaviour is a mutualistic association.

Surprisingly, Labroides dimidiatus reduced the prevalence and abundance of the parasitic isopod Argathona macronema within only $24 \mathrm{~h}$. As part of this same study, Grutter (1999a) also found that cleaners affected the abundance of parasitic gnathiid isopods. Although both studies found evidence of an effect of cleaners, which varied according to whether caged fish were sample overnight (12 h) or for the entire day ( $24 \mathrm{~h})$, in this study an effect of time was only found for the prevalence. These differences between studies are, in part, likely due to the different measures of parasite infection used, as Grutter (1999a) only used abundances of gnathiids. That the effect of cleaners on $A$. macronema prevalence rates (this study) or gnathiid abundances (Grutter 1999a) occurred only in the time period that included daylight hours $(24 \mathrm{~h})$ is not surprising as $L$. dimidiatus are only active during the day (Grutter 1996a). Cleaners also clearly had a large effect on the abundance of $A$. macronema on 'old' fish with only $2 \%$ of all $A$. macronema found on reefs with cleaners after 12 and $24 \mathrm{~h}$ combined.

In contrast, after $12 \mathrm{~d}$, the effect of cleaners on Argathona macronema prevalence and abundance was less clear. Although there was a trend for lower prevalences and abundances on reefs without cleaners, the variation among reefs was high during that experiment. Cleaners only regularly cleaned caged fish for the last 3 to $4 \mathrm{~d}$ of the $12 \mathrm{~d}$ experiment. This suggests that cleaners may have required time to habituate to cages. This effect would have likely been more pronounced in the $12 \mathrm{~d}$ experiment which was run prior to the $24 \mathrm{~h}$ experiment and thus may explain some of the differences observed between the 2 experiments.

\section{Size of Argathona macronema}

Although cleaners had no effect on the size frequency distribution of Argathona macronema in the $24 \mathrm{~h}$ experiment, this is not as surprising since fish on reefs with cleaners had almost no A. macronema. After $12 \mathrm{~d}$, however, cleaners clearly affected the smaller $A$. macronema. The differences between the short- and long-term effect of cleaners on isopod size compared to isopod prevalence and abundance are most likely due to the infection dynamics of the $A$. macronema and the rate at which cleaners removed A. macronema. Over $24 \mathrm{~h}, A$. macronema did not likely have sufficient time to accumulate on fish compared to the rate they were removed by cleaners. In contrast, over $12 \mathrm{~d}$, A. macronema likely had sufficient time to accumulate on fish where the smaller isopods were selectively preyed on. Little is known of the infection dynamics of A. macronema, such as how long they remain on fish and whether this varies according to isopod size. Such information would help clarify the patterns observed in this study.

That cleaners affected the smaller Argathona macronema is in contrast to Gorlick et al.'s (1987) study that found that parasitic copepods on fish were larger in the absence of cleaners. This difference is likely due to the size of copepods which were relatively small $(0.5 \mathrm{~mm})$ compared to the A. macronema in this study. More importantly, however, Gorlick et al.'s (1987) study also suggested this effect was likely due to density dependent population regulation by the parasites themselves with a large copepod preventing new copepods from recruiting onto fish.

Our study, in contrast, agrees with dietary studies of cleaners and measurements of their 'throat width', which indicate that their throat size may limit the maximum size of parasite they can ingest (Grutter 2000). Following methods in Grutter (2000), the estimated 'throat width' of the largest cleaner removed on the reefs was $1.4 \mathrm{~mm}$. It is well known that the diameter (width) of prey may limit a fish's ability to fit the prey into its mouth (Wainwright \& Richard 1995). The size (width) range of Argathona macronema on caged fish was 2.5 (1.09) to 16.6 (6.59) $\mathrm{mm}$. Cleaners, clearly, could not have swallowed the larger individuals whole.

Indeed, whether they could have swallowed even the smaller Argathona macronema is questionable. Cleaners are, however, capable of feeding on large items by tearing pieces off these food items. In the laboratory, Labroides dimidiatus have been observed tearing small pieces from whole prawn (A. Grutter 
pers. obs). Furthermore, a larger (maximum $25 \mathrm{~cm}$ total length of juveniles) juvenile facultative cleaner Coris sandageri has been observed removing a $20 \mathrm{~mm}$ long isopod Codonophilus sp. from a client's mouth then disabling it before eating it by repeatedly striking it against the rocks (Ayling \& Grace 1971). Thus, cleaners may have removed A. macronema, disabled them and eaten them by tearing off small pieces. Regardless of how cleaners affected the A. macronema, it is not difficult to envisage that for fish with such small mouths (Randall 1958), interacting with small prey should be easier than with larger prey, particularly the large size of A. macronema involved in this study.

Although most dietary studies have not recorded Labroides spp. as eating non-gnathiid isopods (Youngbluth 1968, Randall 1958, Grutter 1997), cymothoids were found in the diet of $L$. dimidiatus at Heron Island, Great Barrier Reef (Choat 1969). Cymothoids are also preyed upon by fishes prior to settling on the definitive host (Segal 1987 and references therein). The rarity of such isopods in diet analyses of cleaners is not surprising as non-gnathiid isopods are rare and generally found in low numbers on wild fish, including Hemigymnus melapterus (Lester \& Sewell 1989, Grutter 1994, Bunkley-Williams \& Williams 1998b). In the wild, Argathona macronema has been found on fish such as Plectropomus leopardus and Cromileptis altivelis (Bruce 1982) and on green turtles (Monod 1975). Plectropomus leopardus is regularly cleaned by $L$. dimidiatus (A. Grutter pers. obs.). Because no diet analyses of cleaners were done, other scenarios cannot be excluded: for example, while cleaners fed on gnathiids they may have also disturbed A. macronema, either by the action of feeding on other parasites or by physically removing $A$. macronema without eating them.

\section{Time}

There was some evidence of an effect of time of day on isopod infections. On reefs without cleaners more 'old' fish were infected during the day on reefs than at night. However, this should be interpreted cautiously as few 'new' fish were used over the day. Little is known of the infestation behaviour of these isopods. Some studies have suggested that isopods infect fish at night (Paperna \& Por 1977). Marine isopods form part of the nocturnal migrating zooplankton assemblage (Alldredge \& King 1977) and cirolanid isopods mainly infect fish at night (Stepien \& Brusca 1985). In a separate study, involving caged Hemigymnus melapterus exposed to parasites for 4 to $8 \mathrm{~h}$ at different times of the day and night, and on reefs without cleaners (Grutter 1999b), the only fish that were infected with Argathona macronema (3 fish with 1 to 2 parasites each) were those held in cages at night
(A. Grutter unpubl. data). In contrast, for wild fish, out of $121 \mathrm{H}$. melapterus sampled between dawn and sunset (Grutter 1999b), only 1 fish collected in mid-afternoon had a single $A$. macronema (A. Grutter unpubl. data). Observations at night made in the same area found no evidence of cleaning (A. Grutter pers. obs.).

\section{Effect of replacing fish in $24 \mathrm{~h}$ experiment}

Whether fish that had been held for $12 \mathrm{~d}$ in cages on the reef ('old' fish) were more susceptible to attack by Argathona macronema in the $24 \mathrm{~h}$ experiment than fish that were newly placed into cages ('new' fish) is unclear. On reefs without cleaners more 'old' fish were infected than 'new' fish when sampled overnight and only 'old' fish sampled over the day had A. macronema. The latter result, however, should be interpreted cautiously as only 3 'new' fish were used compared to 18 'old' fish. On reefs with cleaners, the infection rates did not differ between 'old' and 'new' fish held both over the night and day. On reefs with cleaners, abundances were too low to test for an effect of replacing fish. When we found that 'old' fish were more susceptible to $A$. macronema, it was always on reefs without cleaners. Such a pattern may simply be due to the fact that infections were more prevalent and abundant on the caged fish from these reefs making the detection of this effect more likely on these reefs. That fish that had been held in captivity had more $A$. macronema is not surprising as caged fish frequently have more parasite infections (Bragoni et al. 1983, Stepien \& Brusca 1985, Williams \& Bunkley-Williams 1994a).

\section{Avoidance of Argathona macronema by fish}

The vulnerability of confined fish to Argathona macronema may be due to several factors. For cymothoids, not surprisingly, multiple attachments may lead to less vigorous responses due either to fatigue or the effects of wounds (Segal 1987). Thus, once attacked, fish are more susceptible to further attacks by isopods (Segal 1987). In addition, caged fish, which do not have the option of escape, by swimming away or hiding, are at a greater risk of infection by isopods. In the wild, Hemigymnus melapterus seek shelter in crevices in the reef at night and whether such areas afford protection from parasites is unknown.

\section{CONCLUSIONS}

To define cleaning as mutualistic, the benefits to both participants must be demonstrated; however, 
clear benefits for both parties in supposedly mutualistic interactions have rarely been demonstrated empirically (Cushman \& Beattie1991). It is clear that cleaner fish benefit from cleaning as they obtain food (Youngbluth 1968, Grutter 1996a, 1997). The present study demonstrates that the cleaner fish Labroides dimidiatus reduces Argathona macronema isopod infections on a caged coral reef fish at Lizard Island over a period of hours. Whether fish benefit from the removal of isopods remains to be determined. That the above effect occurred with caged fish shows the potential of tropical cleaners, in addition to temperate cleaners (Costello 1995), as useful biological control agents of parasites of caged fish.

Acknowledgements. We thank C. Bansemer, R. Carpenter, M. Johnson, M. Srinivasi, R. Tollrian and the Lizard Island Research Station staff for their assistance in the field and K. Jennings, J. M. Murphy, and A. Schmidt for laboratory assistance. We are grateful to J. Hendrikz for statistical advice and N. Bruce for identifying the isopods. The Australian Research Council supported this research with a Small Grant and an Australian Postdoctoral Fellowship to A.S.G.

\section{LITERATURE CITED}

Adlard RD, Lester RJG (1994) Dynamics of the interaction between the parasitic isopod, Anilocra pomacentri, and the coral reef fish, Chromis nitida. Parasitology 109: 311-324

Alldredge AL, King JM (1977) Distribution, abundance, and substrate preferences of demersal reef zooplankton at Lizard Island Lagoon, Great Barrier Reef. Mar Biol 41: 317-333

Ayling AM, Grace RV (1971) Cleaning symbiosis among New Zealand fishes. NZ J Mar Freshw Res 5:205-218

Bowman TE (1977) Isopod crustaceans (except Anthuridae) collected on the Presidential Cruise of 1938. Proc Biol Soc Wash 89:653-666

Bragoni G, Romestand B, Trilles JP (1983) Parasitism by cymothoids among sea-bass (Dicentrarchus labrax Linneus) in rearing. II. Parasitic ecophysiology in Diana Pond, Corsica. Ann Parasitol Hum Comp 58:593-609

Bruce NL (1982) Species of Argathona Stebbing, 1905 (Isopoda, Corallanidae) new to Australia, with description of two new species. Crustaceana 42:12-25

Bunkley-William L, Williams EH Jr (1998a) Ability of Pederson cleaner shrimp to remove juveniles of the parasitic cymothoid isopod, Anilocra haemuli, from the host. Crustaceana 71:826-869

Bunkley-Williams L, Williams EH Jr (1998b) Isopods associated with fishes: a synopsis and corrections. Parasitology 84(5):893-896

Burreson EM, Dybdahl RE (1989) Richardsonobdella lineatae, gen. et sp. nov. (Hirudinea), a parasite of Meiacanthus lineatus (Pisces: Blenniidae) from Heron Island, Great Barrier Reef. Aust J Zool 37:89-93

Chi SC, Lo CF, Kou GH, Chang PS, Peng SE, Chen SN (1997) Mass mortalities associated with viral nervous necrosis (VNN) disease in two species of hatchery-reared grouper, Epinephelus fuscoguttatus and Epinephelus akaara (Temminck and chlegel). J Fish Dis 20(3):185-193
Chisholm LA, Whittington ID (1996) Descriptions of the larvae of six species of monocotylid monogeneans from Himantura fai (Dasyatididae) and Rhinobatos typus (Rhinobatidae) from Heron Island, Great Barrier Reef, Australia. Syst Parasitol 35:145-156

Choat JH (1969) Studies on Labroid fishes. II. A comparative study of the ecology of the labridae and scaridae. $\mathrm{PhD}$ thesis, University of Queensland, p 1-140

Costello MJ (1995) Development and future of cleaner-fish technology and other biological control techniques in fish farming. In: Sayer MDJ, Treasurer JW, Costello MJ (eds) Wrasse: biology and use in aquaculture. Fishing News Books, Oxford, p 171-184

Cowell LE, Watanabe WO, Head WD, Grover JJ, Shenker JM (1993) Use of tropical cleaner fish to control the ectoparasite Neobenedenia meleni (Monogenea: Capsalidae) on seawater-cultured Florida red tilapia. Aquaculture 113: $189-200$

Cushman JH, Beattie AH (1991) Mutualisms: assessing the benefits to hosts and visitors. Trends Ecol Evol 6(6): 193-195

Delaney PM (1989) Phylogeny and biogeography of the marine isopod family Corallanidae (Crustacea, Isopoda, Flabellifera). Contrib Sci 409:1-75

Diggles BK, Lester RJG (1996) Infections of Cryptocaryon irritans on wild fish from south-east Queensland. Dis Aquat Org 25:159-167

Gorlick DL, Atkins PD, Losey GS (1987) Effect of cleaning by Labroides dimidiatus (Labridae) on an ectoparasite population infecting Pomacentrus vaiuli (Pomacentridae) at Enewetak Atoll. Copeia 1987:41-45

Grutter AS (1994) Spatial and temporal variations of the ectoparasites of seven reef fish species from Lizard Island and Heron Island, Australia. Mar Ecol Prog Ser 115:21-30

Grutter AS (1995) Relationship between cleaning rates and ectoparasite loads in coral reef fishes. Mar Ecol Prog Ser 118:51-58

Grutter AS (1996a) Parasite removal rates by the cleaner wrasse Labroides dimidiatus. Mar Ecol Prog Ser 130: 61-70

Grutter AS (1996b) Experimental demonstration of no effect by the cleaner wrasse Labroides dimidiatus (Cuvier and Valenciennes) on the host fish Pomacentrus moluccensis (Bleeker). J Exp Mar Biol Ecol 196:285-298

Grutter AS (1997) Spatio-temporal variation and feeding selectivity in the diet of the cleaner fish Labroides dimidiatus. Copeia 1997(2):346-355

Grutter AS (1999a) Cleaner fish really do clean. Nature 398: 672-673

Grutter AS (1999b) Infestation dynamics of parasitic gnathiid isopod juveniles on a coral reef fish Hemigymnus melapterus. Mar Biol 135:545-552

Grutter AS (2000) Ontogenetic variation in the diet of the cleaner fish Labroides dimidiatus and its ecological consequences. Mar Ecol Prog Ser 197:241-246

Grutter AS (2001) Parasite infection rather than tactile stimulation is the proximate cause of cleaning behaviour in reef fish. Proc R Soc Lond B 268:1-5

Grutter AS, Poulin R (1998) Cleaning of coral reef fishes by the wrasse Labroides dimidiatus: influence of client body size and phylogeny. Copeia 1998:120-127

Grutter AS, McCallum H, Lester RJG (2002) Optimising cleaning behaviour: minimising the costs and maximising ectoparasite removal Mar Ecol Prog Ser 234:257-264

Ho J, Tonguthai K (1992) Flabelliferan isopods (Crustacea) parasitic on freshwater fishes of Thailand. Syst Parasitol 21:203-210 
Koesharyani I, Zafran, Yuasa K, Hatai K (1999) Two species of capsalid monogeneans infecting cultured humpback grouper Cromileptes altivelis in Indonesia. Fish Pathol 34: 165-166

Kuwamura T (1976) Different responses of inshore fishes to the cleaning wrasse, Labroides dimidiatus, as observed in Sirahama. Publ Seto Mar Biol Lab Spec Publ Ser 23: 119-144

Lester RJG, Roubal FR (1995) Arthropoda. In: Woo PTK (ed) Diseases of fish, Vol 1. CAB Press, Wallingford, p 475-598

Lester RJG, Sewell KB (1989) Checklist of parasites from Heron Island, Great Barrier Reef. Aust J Zool 37:101-128

Limbaugh C (1961) Cleaning symbiosis. Sci Am 205:(2):42-49

Losey GS Jr (1972) The ecological importance of cleaning symbiosis. Copeia 1972:820-833

Losey GS Jr (1979) Fish cleaning symbiosis: proximate causes of host behaviour. Anim Behav 27:669-685

Losey GS Jr (1987) Cleaning symbiosis. Symbiosis 4:229-258

Monod T (1975). Sur un Argathona (Crustacea, Isopoda) de Kenya. Bull Mus Natl Hist Nat Zool 226:999-1004

Paperna I, Por FD (1977) Preliminary data on the Gnathiidae (Isopoda) of the Northern Red Sea, the Bitter Lakes and the Eastern Mediterranean and the biology of Gnathia piscivora n. sp. Rapp Comm Int Mer Medit 24(4):195-197

Potts GW (1973) The ethology of Labroides dimidiatus (Cuv. \& Val.) (Labridae, Pisces) on Aldabra. Anim Behav 21: 250-291

Randall JE (1958) A review of the Labrid fish genus Labroides, with description of two new species and notes on ecology. Pac Sci 12:327-347

Rohde K, Hayward C, Heap M, Gosper D (1994) A tropical assemblage of ectoparasites: Gill and head parasites of Lethrinus miniatus (Teleostei, Lethrinidae). Int J Parasitol 24:1031-1053

Roubal FR (1995) Changes in monogenean and copepod infestation on captive Acanthopagrus australis (Sparidae). J Fish Biol 46:423-431

Editorial responsibility: Otto Kinne (Editor),

Oldendorf/Luhe, Germany
Segal E (1987) Behaviour of juvenile Nerocila acuminata (Isopoda, Cymothoidae) during attack, attachment and feeding on fish prey. Bull Mar Sci 41:351-360

Stepien CA, Brusca RC (1985) Nocturnal attacks on nearshore fishes in southern California by crustacean zooplankton. Mar Ecol Prog Ser 25:91-105

Wainwright PC, Richard BA (1995) Predicting patterns of prey use from morphology of fishes. Environ Biol Fish 44: 97-113

Weeks P (2000) Red-billed oxpeckers: vampires or tickbirds? Behav Ecol 11:154-160

Whittington ID (1998) Diversity 'down under': Monogeneans in the Antipodes (Australia) with a prediction of monogenean biodiversity worldwide. Int J Parasitol 28:1481-1493

Wicksten MK (1998) Behaviour of cleaners and their client fishes at Bonaire, Netherlands Antilles. J Nat Hist 32:13-30

Williams EH Jr, Bunkley-Williams L (1994a) Four cases of unusual crustacean-fish associations and comments on parasitic processes. J Aquat Anim Health 6:202-208

Williams EH Jr, Bunkley-Williams L (1994b) New host and locality records for copepod and isopod parasites of Columbian marine fishes. J Aquat Anim Health 6:362-364

Williams EH Jr, Bunkley-Williams L (1996) Parasites of offshore, big game sport fishes of Puerto Rico and Western North Atlantic: a report. Puerto Rico Department of Natural and Environmental Resources, San Juan, Puerto Rico, and Department of Biology, University of Puerto Rico, Mayaguez, p 1-384

Youngbluth MJ (1968) Aspects of the ecology and ethology of the cleaning fish, Labroides phthirophagus Randall. Z Tierpsychol 25:915-932

Zafran, Koesharyani I, Johnny F, Yuasa K, Harada T, Hatai K (2000) Viral nervous necrosis in humpback grouper Cromileptes altivelis larvae and juveniles in Indonesia. Fish Pathol 35:95-96

Zar JH (1999) Biostatistical analysis. Prentice Hall International, Sidney

Submitted: July 2, 2001; Accepted: November 27, 2001

Proofs received from author(s): May 2, 2002 